\title{
The influence of impurities in high temperature polymer electrolyte membrane fuel cells performance
}

\author{
Marta Boaventura*, Isabel Alves, Paulo Ribeirinha, Adélio Mendes* \\ LEPABE - Faculdade de Engenharia, Universidade do Porto, Rua Dr. Roberto Frias, 4200-465 Porto, \\ Portugal \\ (*) corr. authors: mendes@fe.up.pt, marta.boaventura@fe.up.pt
}

\begin{abstract}
This work investigates the influence of carbon dioxide and non-reacted methanol, present in the reformate stream obtained via methanol steam reforming, in the performance of high temperature polymer electrolyte membrane fuel cells (HT-PEMFC), operating between $160{ }^{\circ} \mathrm{C}$ and $180{ }^{\circ} \mathrm{C}$.

The HT-PEMFC anode was fed with pure hydrogen, hydrogen balanced with carbon dioxide (75\% / $25 \%$ vol.) and synthetic reformate mixture, considering also vaporized methanol solution in the reformate content (up to $10 \%$ vol.). The synthetic reformate was feed during cycles of $420 \mathrm{~min}$. The fuel cell was characterized based on the polarization curve and electrochemical impedance spectroscopy (EIS) analysis. Additionally, acid-base titrations were performed to access the phosphoric acid content in different sections of the MEAs as well as scanning electron microscopy (SEM).

A low impact in the fuel cell performance was observed when three cycles of synthetic reformate containing methanol solution were performed. When the number of cycles was increased, the performance of HT-PEMFC decreases and irreversible degradation of performance was observed. The cycles with synthetic reformate increased the ohmic resistance and high frequency resistance associated with anodic processes, but decreased the intermediate frequency resistance associated with cathodic processes. Additionally, by increasing the number of cycles, the phosphoric acid content of Celtec ${ }^{\circledR}$ MEAs and the thickness of the membrane decreased.
\end{abstract}

\section{Keywords:}

Polymer electrolyte membrane fuel cell

Polybenzimidazole

Reformate gas

Methanol

Impurities effect

Electrochemical impedance spectroscopy 


\section{Introduction}

Polymer electrolyte membrane fuel cells (PEMFC) are electrochemical devices that have been considered for stationary applications and as an alternative to internal combustion engines. PEMFC are limited to a maximum operating temperature of $90{ }^{\circ} \mathrm{C}$ due to use of perfluorinated membranes as electrolyte, which presents very high conductivity under humidified conditions. The increase of operation temperature of PEMFC is desirable due to electrochemical kinetics improvements, simplified water management, heat recovery and increased $\mathrm{CO}$ tolerance [1]. High temperature polymer electrolyte membrane fuel cells (HT-PEMFC) operate between $160{ }^{\circ} \mathrm{C}$ and $180{ }^{\circ} \mathrm{C}$ and are based on phosphoric acid doped polybenzimidazole (PBI) membrane.

PEMFC devices can achieve high power densities, without any emissions besides water vapor, when pure hydrogen is fed to the anode. Hydrogen storage systems do not present yet the required capacity, cost and operating simplicity. Hydrogen can be produced by the reforming of fuels such as methane, methanol or ethanol and then feed to the fuel cell. Due to its high hydrogen/carbon ratio and absence of carbon to carbon bonds, methanol is a more attractive fuel for in-situ hydrogen production. Additionally, methanol can be used directly in direct methanol fuel cells (DMFC), but they present considerably lower performance [2] due to poor oxidation kinetics and methanol crossover from the anode to the cathode.

A high temperature DMFC was first studied in the 1990's using phosphoric acid doped PBI as electrolytes [3-5]. The assembled DMFC reached a maximum of $0.1 \mathrm{~W} \cdot \mathrm{cm}^{-2}$, at $200{ }^{\circ} \mathrm{C}$ [4]. More recently, a PBI-based HT-DMFC was used by Lobato et al. to study the effect of temperature, methanol/water ratio, and oxygen partial pressure [6]; a power peak close to $0.14 \mathrm{~W} \cdot \mathrm{cm}^{-2}$ was obtained at $200{ }^{\circ} \mathrm{C}$.

Methanol steam reforming (MSR) reaction is an endothermic reaction, producing hydrogen and carbon dioxide; the presence of carbon monoxide in the reaction products can be attributed to side reactions, namely methanol decomposition and reverse water gas shift. The effect of $\mathrm{CO}_{2}$ and especially $\mathrm{CO}$ on the performance of HT-PEMFCs was reported by several authors [7-11]. CO adsorbs strongly on platinum surface, used as electrocatalyst, reducing its activity. A good tolerance (voltage loss within 30-50mV) of a Pt /C catalyst was observed with $3 \%$ and $5 \%$ of CO at $180^{\circ} \mathrm{C}$, at moderate values of cell voltage [10]. The presence of $\mathrm{CO}_{2}$ in the reformate dilutes the fuel and limits the maximum current density of the fuel cell and can have a negative effect due to formation of $\mathrm{CO}$ via the reverse water-gas shift reaction on platinum surface [12].

Pan et al. integrated a HT-PEMFC stack, based on acid-doped PBI membranes, with a MSR [13]. The reformate was directly fed into the stack and a voltage decrease was seen in all current density range 
when compared with pure hydrogen; one of the factors may be the effect of residual methanol from the reformer. Su et al. [14] integrated a methanol fuel reformer positioned upstream of a HT-PEMFC and observed a decrease in the fuel cell power peak from $0.22 \mathrm{~W} \cdot \mathrm{cm}^{-2}$ to $0.12 \mathrm{~W} \cdot \mathrm{cm}^{-2}$, when pure hydrogen was replaced by methanol reformate obtained at $240{ }^{\circ} \mathrm{C}$, due to the presence of $\mathrm{CO}$ and $\mathrm{CO}_{2}$. Avgouropoulos et al. [15-17] proposed the internal methanol reforming by incorporating the reforming catalyst in the HT-PEMFC anodic compartment. In the latest communication [17], the MSR catalyst was deposited on a gas diffusion layer and was separated from the MEA by a plate, being in indirect contact. The authors reported a cell voltage of $642 \mathrm{mV}$ at $0.2 \mathrm{~A} \cdot \mathrm{cm}^{-2}$, at $210{ }^{\circ} \mathrm{C}$, when the anode was supplied with a mixture of methanol, water and helium.

Up to now, very few studies were performed concerning the effect of methanol slip from the MSR on the performance of HT-PEMFC. Methanol oxidation presents a complex reaction mechanism, being several orders of magnitude slower than $\mathrm{H}_{2}$ oxidation [18]. Furthermore, the possible permeation of methanol via diffusion from the anode to the cathode (e.g. during a transient) depolarizes the cathode and reduces $\mathrm{O}_{2}$ availability [5]. Araya et al. [19] performed a HT-PEMFC durability test, at $0.2 \mathrm{~A} \cdot \mathrm{cm}^{-2}$ and $160{ }^{\circ} \mathrm{C}$; the degradation rate increased when pure hydrogen was replaced with hydrogen/ methanolwater vapor mixture (5\% or $8 \%$ vol.). The same research group analyzed the effects of methanol and water vapor on the performance of HT-PEMFC, between $140{ }^{\circ} \mathrm{C}$ and $180{ }^{\circ} \mathrm{C}$ [20]. The authors observed a negligible effect when simulated stream considering methanol reforming conversion of $90 \%$ (3\% vol. methanol vapor) was used in the anode gas feed. Both studies did not consider the influence of $\mathrm{CO}_{2}$ and $\mathrm{CO}$ but in another study the authors performed a multilevel factorial design of experiments to evaluate the interdependence among the concentrations of unconverted methanol-water vapor mixture, $\mathrm{CO}$ and $\mathrm{CO}_{2}$ in gas feed [21]. The poisoning effect on the fuel cell by the methanol showed to be more pronounced when other impurities were also present in the feed gas, especially at higher methanol concentrations.

Understanding the influence of contaminants present in the reformate stream on the HT-PEMFC performance is vital for power supplies with reformate fuel feed development. This work aims to study the influence of methanol-water vapor mixture slip (up to $10 \%$ vol.) and $\mathrm{CO}_{2}$ (up to $25 \%$ vol.) on the performance of HT-PEMFC, working at moderate current density. The supply of reformate containing methanol solution was performed in cycles of $420 \mathrm{~min}$ at $0.6 \mathrm{~A} \cdot \mathrm{cm}^{-2}$. These conditions are more extreme than the ones already reported, in an attempt to understand clearly the effect of methanol slip. 


\section{Experimental}

The MEAs used in this study were Celtec ${ }^{\circledR}$ - P2100 MEA from BASF Fuel Cell, with an active area of $45 \mathrm{~cm}^{2}$. The MEAs were activated accordingly to supplier's specifications, at constant load of $0.20 \mathrm{~A} \cdot \mathrm{cm}^{-2}$ and at $160{ }^{\circ} \mathrm{C}$ for at least $50 \mathrm{~h}$, with stoichiometry of 2 for air and 1.2 for hydrogen. After activation and during experiments the MEAs are operated with stoichiometry of 1.5 for hydrogen.

The tested were carried out in an in-house made fuel cell test bench, described elsewhere [22], using a Pragma single cell assembled with a torque of $5.5 \mathrm{~N} \cdot \mathrm{m}$. The experimental conditions were controlled using an application developed in LabView (National Instruments) and the electrochemical tests were performed using a Zahner IM6e electrochemical workstation coupled with a potentiostat PP-241.

In the experiments, besides pure hydrogen, gas mixtures were used to evaluate the effect of impurities: hydrogen balanced with carbon dioxide (75\% / 25\% vol., hereafter referred as carbon dioxide mixture) and hydrogen balanced with carbon dioxide and methanol solution, hereafter referred as synthetic reformate. The experiments with synthetic reformate were performed in cycles of 420 minutes, at constant $0.6 \mathrm{~A} \cdot \mathrm{cm}^{-2}$, starting with two cycles with $7 \%$ vol. methanol solution (and therefore $18 \%$ of carbon dioxide) followed with cycles with $10 \%$ vol. methanol solution (and therefore $15 \%$ of carbon dioxide). The synthetic reformate stream was produced using a methanol evaporating system comprising a methanol solution (steam to carbon ratio of 1.5) reservoir, a HPLC pump to provide the desired amount of liquid and an evaporator. Between cycles, overnight, pure hydrogen was used as anode fuel and the single cell was kept at constant $0.2 \mathrm{~A} \cdot \mathrm{cm}^{-2}$.

Different MEAs were used during experiments, labelled from 1 to 4: MEA 1 was characterized with hydrogen, carbon dioxide mixture and 3 cycles of synthetic reformate; in MEA 2 and MEA 3 the number of synthetic reformate was increased to 7 and 18, respectively; MEA 4 was characterized at $180^{\circ} \mathrm{C}$ with hydrogen, carbon dioxide mixture and 3 cycles of synthetic reformate.

The electrochemical characterization included polarization curves and electrochemical impedance spectroscopy (EIS). After the $3^{\text {rd }}, 7^{\text {th }}$ and $18^{\text {th }}$ synthetic reformate cycles, the Celtec ${ }^{\circledR}$ MEAs were characterized using pure hydrogen. During each synthetic reformate cycle the electric potential difference was registered and EIS was performed. Polarization curves were obtained galvanostatically between $0.05 \mathrm{~A} \cdot \mathrm{cm}^{-2}$ and $0.8 \mathrm{~A} \cdot \mathrm{cm}^{-2}$. EIS were obtained at $0.6 \mathrm{~A} \cdot \mathrm{cm}^{-2}$, between $100 \mathrm{kHz}$ and $100 \mathrm{mHz}$ with a perturbation amplitude of $5 \mathrm{mV}$.

After the electrochemical characterization, acid-base titrations were performed for determining the phosphoric acid content in the different sections of the MEA. The samples were cut with a mallet handle die, delaminated and placed in a glass beaker containing a 2-propanone solution. The solution was stirred using magnetic stirrer for at least $30 \mathrm{~min}$ and then titrated with sodium hydroxide solution. Also, 
all the MEAs were characterized by field emission scanning electron microscopy (SEM) to observe possible microscopic changes in the MEA structure after the electrochemical characterization.

\section{Results and Discussion}

\subsection{Fuel cell performance}

The effect on the performance of the HT-PEMFC by $\mathrm{CO}_{2}$ and methanol solution present in hydrogen stream was studied switching the anode feed from pure hydrogen to the carbon dioxide mixture and then to synthetic reformate cycles, at $0.6 \mathrm{~A} \cdot \mathrm{cm}^{-2}$.

Figure 1 and Figure 2 show the polarization curves obtained at $160{ }^{\circ} \mathrm{C}$ and $180{ }^{\circ} \mathrm{C}$, with pure hydrogen and $\mathrm{CO}_{2}$ mixture. For comparison, the voltage value at the end of the $3^{\text {rd }}, 7^{\text {th }}$ and $18^{\text {th }}$ synthetic reformate cycles were added (full symbols). Pure hydrogen was used as fuel after synthetic reformate cycles in order to evaluate the influence of cycles and possible degradation of fuel cell performance.

The performance of MEAs 1-4 with pure hydrogen, obtained just after activation, exhibit differences showing that the cells have not been activated to the same extent (being higher for MEA 3 and lower for MEA 4) despite the similar activation time, as already observed by Tingelof and Ihonen [23]. For all MEAs there were no significant changes in the fuel cell voltage, for all current density range, when pure $\mathrm{H}_{2}$ was replaced by the $\mathrm{CO}_{2}$ mixture (Figure 1 and Figure 2). The maximum decrease at $0.6 \mathrm{Acm}^{-2}$, $15 \mathrm{mV}$, was observed for MEA 3. In low temperature PEMFCs, the formation of CO via the reverse water-gas shift reaction on platinum surface can affect the anode catalyst activity [12], however, at high temperatures such $160{ }^{\circ} \mathrm{C}-180^{\circ} \mathrm{C}$, the $\mathrm{CO}$ adsorption is disfavored and the removal by electro-oxidation of adsorbed species favored. Additionally, in the present work, the hydrogen stoichiometry was kept when pure hydrogen was replaced by the $\mathrm{CO}_{2}$ mixture and the small decrease in the voltage values can be associated mainly with a dilution effect. It was already reported that $\mathrm{CO}_{2}$ has a slight effect on the performance of HT-PEMFC based on phosphoric acid doped PBI, if present in the anode feed as the sole impurity, but in the presence of $\mathrm{CO}$ and/or methanol-water vapor mixture, the collective effect of impurities is greater than the sum of the individual effects [21]. A similar trend for HT-PEMFC performance was observed for the coupled effect of $\mathrm{CO}$ and $\mathrm{N}_{2}$, showing the importance of analyzing the combined effect of impurities [9]. 


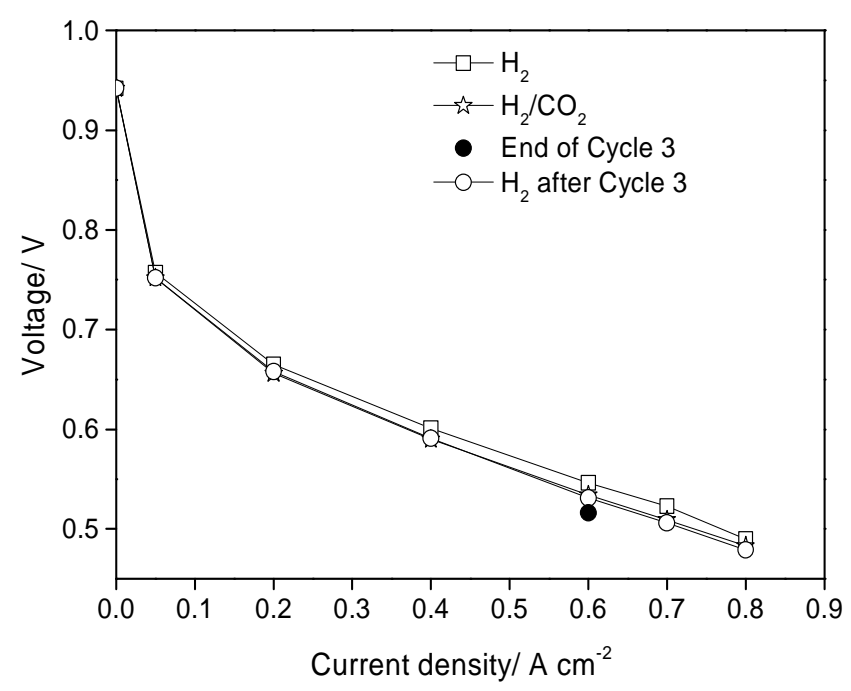

(a)

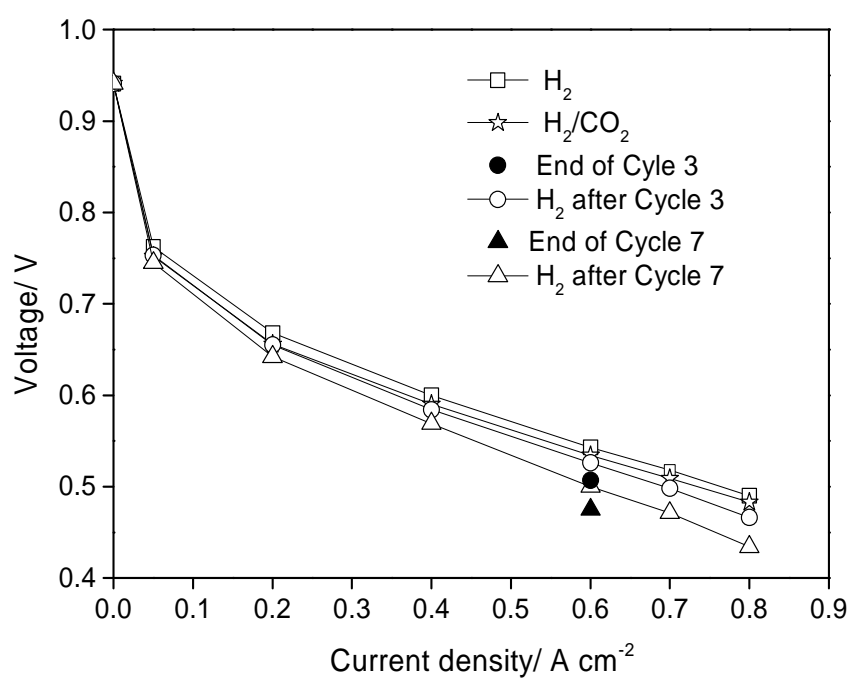

(b) 


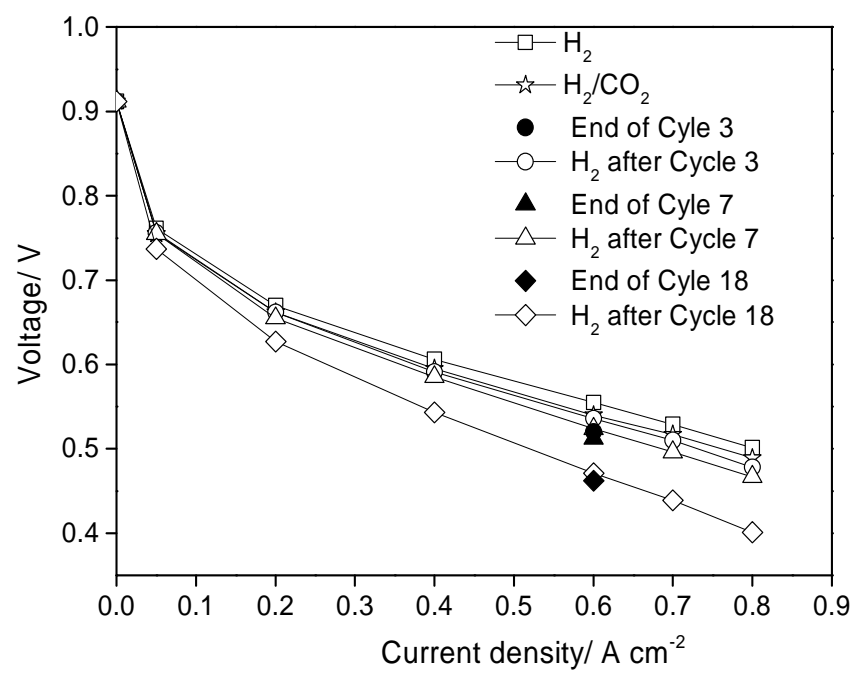

(c)

Figure 1 Polarization curves obtained for MEA 1 (a), MEA 2 (b) and MEA 3 (c), at $160^{\circ} \mathrm{C}$, using different fuels: pure hydrogen $(\square, O, C$ and $G)$, carbon dioxide mixture (*) and synthetic reformate at cycles 3,7 and $18(\bullet, \boldsymbol{\Delta}$ and $\mathrm{m})$.

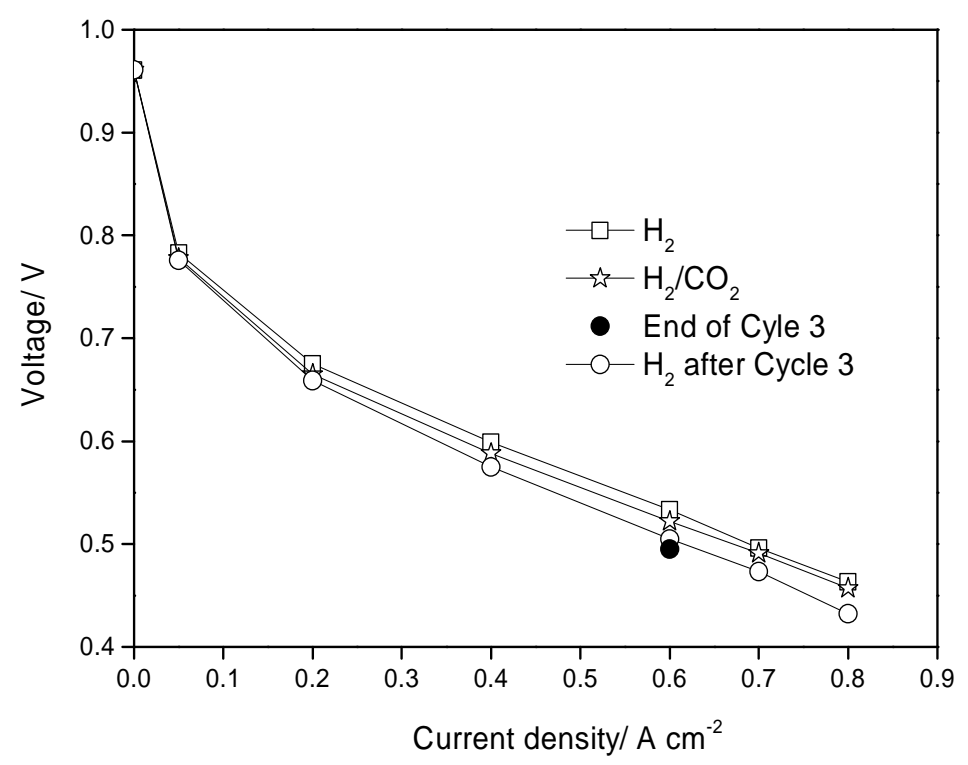

Figure 2 Polarization curves obtained for MEA 4, at $180{ }^{\circ} \mathrm{C}$ for different anode fuels: hydrogen $(\square, \bigcirc)$, carbon dioxide balanced hydrogen $(*)$. Full symbol represent the voltage obatined when synthtic reformate was fed at $0.6 \mathrm{~A} \mathrm{~cm}^{-2}(\bullet)$.

The full symbols in Figure 1 and Figure 2, representing the voltage obtained when synthetic reformate was fed to the fuel cell anode at $0.6 \mathrm{~A} \cdot \mathrm{cm}^{-2}$, decreased for MEAs 1-3 (tested at $160{ }^{\circ} \mathrm{C}$ ) and MEA 4 
(tested at $180^{\circ} \mathrm{C}$ ), when the fuel was switched from pure hydrogen to synthetic reformate. At the end of the $3^{\text {rd }}$ cycle, the voltage decreased $30 \mathrm{mV}, 36 \mathrm{mV}$ and $33 \mathrm{mV}$ for MEA 1, MEA 2 and MEA 3, respectively, when compared to the voltage value obtained with pure hydrogen. For MEA 4 (tested at $180{ }^{\circ} \mathrm{C}$ ), Figure 2 , the voltage value at the end of the $3^{\text {rd }}$ cycle decreased $38 \mathrm{mV}$. Methanol can react at the anode platinum surface and the methanol - water solution can have an impact on the hydration/dehydration of the phosphoric acid on the membrane and catalyst layers and leaching of phosphoric acid from the MEA. Moreover, operating at higher temperature $\left(180{ }^{\circ} \mathrm{C}\right)$ even with pure hydrogen, can increase the charge transfer resistance and phosphoric acid losses due to fast evaporation from the electrodes [24]. The increase number of synthetic reformate cycles for MEA 2 and MEA 3, lead to further decrease in the voltage value at $0.6 \mathrm{~A} \cdot \mathrm{cm}^{-2}$, namely 68 and $43 \mathrm{mV}$ for MEA 2 and MEA 3, respectively, after 7 reformate cycles and $93 \mathrm{mV}$ for MEA 3 after 18 cycles (Figure 1). The discrepancy may be due to the higher initial performance of MEA 3 when compared to MEA 2.

The voltage values obtained with pure hydrogen, at $0.6 \mathrm{~A} \cdot \mathrm{cm}^{-2}$, after 3, 7, and 18 cycles (Figure 1 and Figure 2) are higher than the voltage values obtained at the end of the synthetic reformate cycles. However, the initial performance obtained just after activation with pure $\mathrm{H}_{2}$ was not reached, showing only a partial recovery in the fuel cell performance. This is consistent with the observation made by Araya et al. [19] during overall durability tests, at $160{ }^{\circ} \mathrm{C}$. The authors observed a degradation rate of 5 $\mu \mathrm{V} \cdot \mathrm{h}^{-1}$ when pure hydrogen was used as fuel and $900 \mu \mathrm{V} \cdot \mathrm{h}^{-1}$ and $3.4 \mathrm{mV} \cdot \mathrm{h}^{-1}$ when $5 \%$ vol. and for $8 \%$ vol. of methanol solution was present at the anode feed, respectively, at $0.2 \mathrm{~A} \cdot \mathrm{cm}^{-2}$; lower concentrations of methanol solution were tested afterwards, and a partial recovery in the HT PEMFC performance was observed.

For the MEAs 1-4 the polarization curves obtained with pure hydrogen, after three cycles performed with synthetic reformate, are close to the ones obtained for the $\mathrm{CO}_{2}$ mixture previously to the synthetic reformate cycles, Figure 1. For MEAs 2 and 3 was observed a decrease in voltage vales after the $7^{\text {th }}$ cycle with synthetic reformate, especially at current densities higher than $0.2 \mathrm{~A} \cdot \mathrm{cm}^{-2}$, Figure 1 (b) and (c). Additionally, for MEA 3, a decrease in voltage values was visible, for all current density range, after the $18^{\text {th }}$ cycle with synthetic reformate, Figure 1 (c).

\subsection{EIS}

In attempt to clarify the origin of voltage loss and the irreversible degradation, EIS was performed at $0.6 \mathrm{~A} \cdot \mathrm{cm}^{-2}$ for the MEAs 1-4, Figure 3 and Figure 4. The spectra presented for the synthetic reformate were obtained at the end of each cycle. 


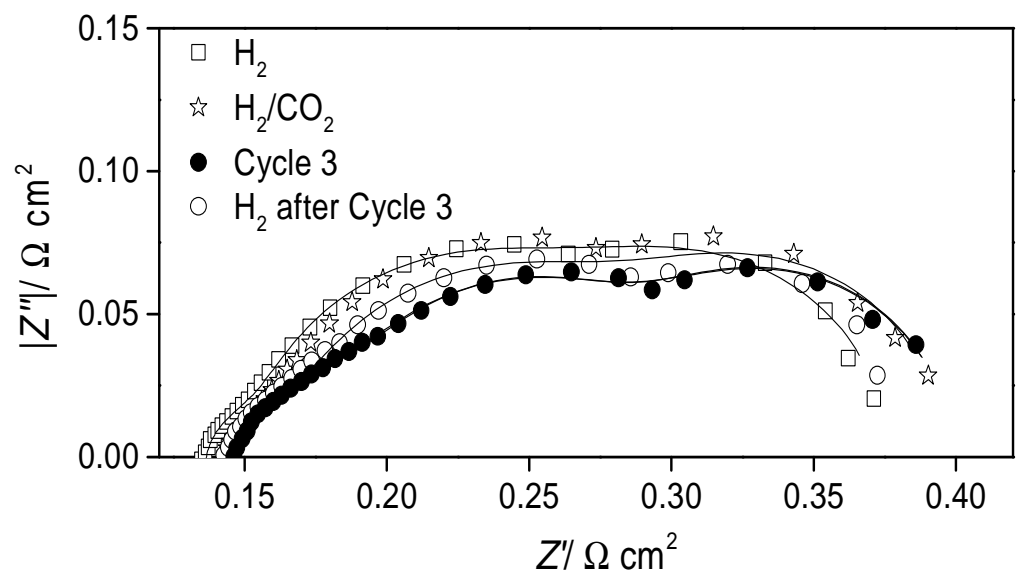

(a)

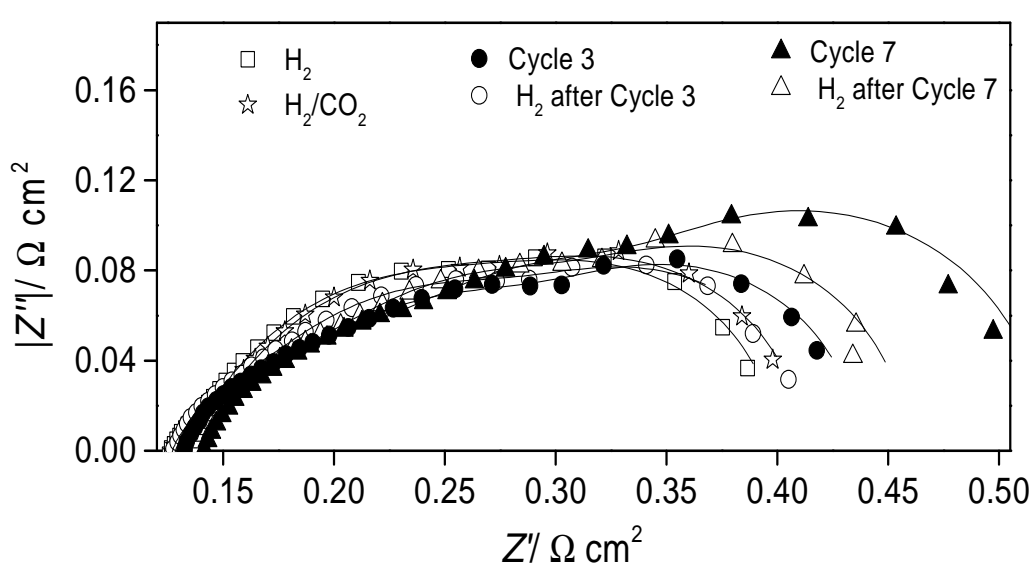

(b)

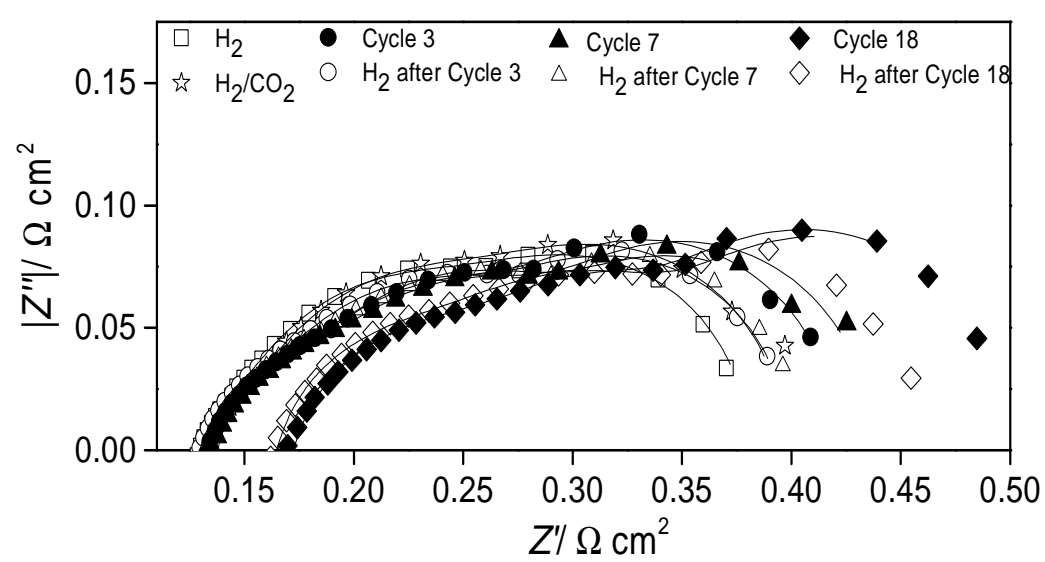

(c)

Figure 3 Nyquist plots for MEA 1 (a), MEA 2 (b) and MEA 3 (c), at $160^{\circ} \mathrm{C}$ and $0.6 \mathrm{~A} \cdot \mathrm{cm}^{-2}$ for different anode fuels: pure hydrogen $(\square, O, C$ and $G)$, carbon dioxide mixture (*) and synthetic reformate at cycles 3, 7 and $18(\bullet, \Delta$ and $\mathrm{m})$. Lines represent the fitting electrical equivalent model. 


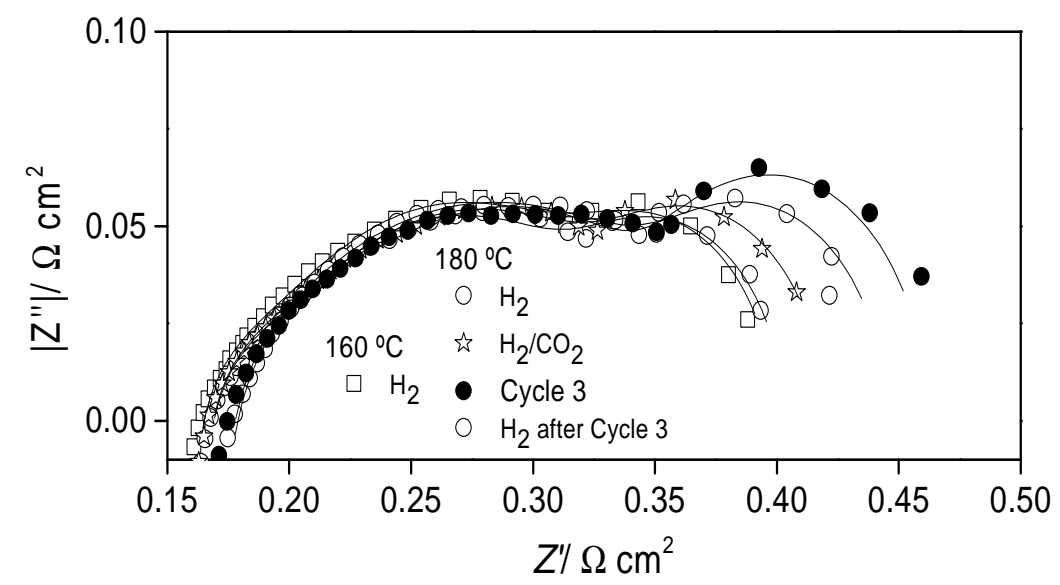

Figure 4 Nyquist plots for MEA 4, at $180^{\circ} \mathrm{C}$, at $0.6 \mathrm{~A} \cdot \mathrm{cm}^{-2}$ for different anode fuels: pure hydrogen $(\square$, $O, C$ and $G$ ), carbon dioxide mixture $(*)$ and synthetic reformate at cycles $3(\bullet)$. Lines represent the fitting electrical equivalent model.

For the interpretation of EIS spectra, an equivalent electric model was used. A typical fuel cell electrical equivalent circuit is divided in anode and cathode analogs (for high and intermediate frequencies, respectively), mass transfer analog (for low frequencies) and ohmic losses $\left(R^{\Omega}\right)$, connected in series. Each electrode is represented by a charge transfer resistance $(R)$ in parallel with a constant phase element $\left(C_{d l}\right)$. The transfer of reactants to the active sites is represented by a resistance/condenser $(R / C)$. An inductance was added to represent the inductance of the cables at high frequencies, originating the equivalent circuit of Figure 5.

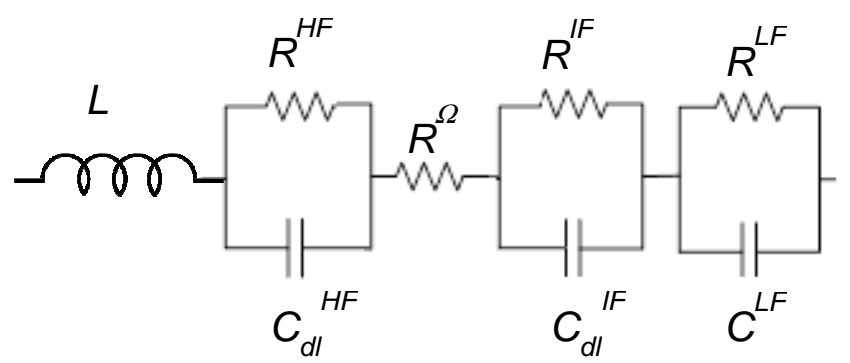

Figure 5 Fuel cell electrical equivalent circuit.

The SIM module from Thales software (Zahner-Elektrik GmbH) was used to fit the model to the experimental data (full lines in Figure 3 and Figure 4). The fitting parameters can be seen in Figure 6 and Figure 7. 


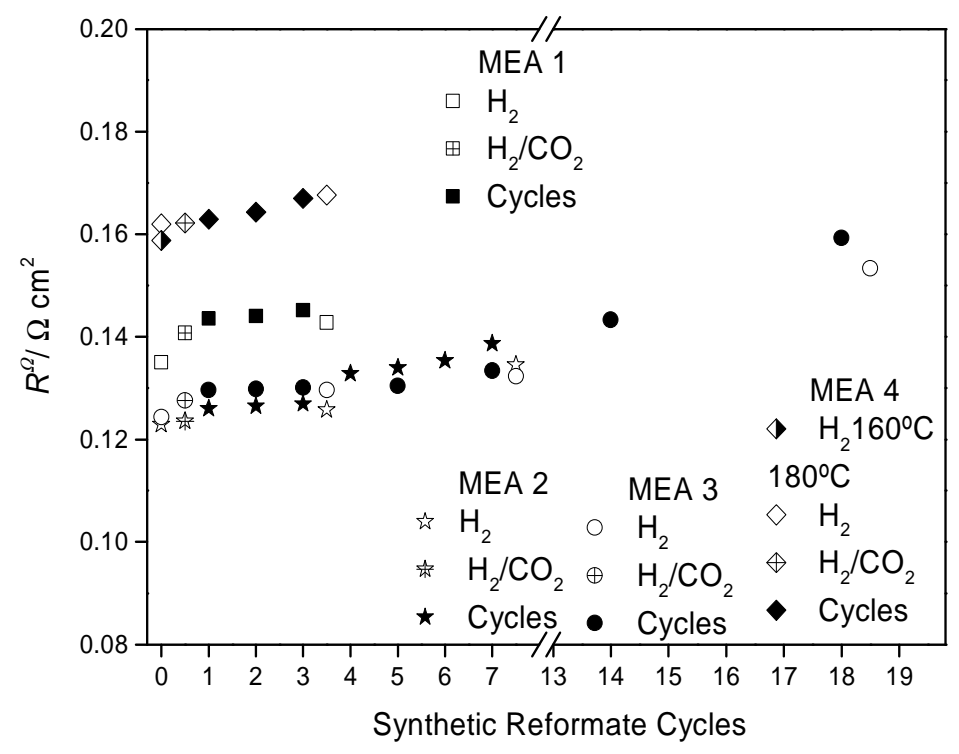

Figure 6 Fitted ohmic resistances for MEAs 1-4 and $0.6 \mathrm{~A} \cdot \mathrm{cm}^{-2}$ using different fuels: pure hydrogen (open and half-filled symbols), carbon dioxide mixture (crossed symbols) and synthetic reformate (full symbols), at $160{ }^{\circ} \mathrm{C}$ and $180^{\circ} \mathrm{C}$.

The ohmic resistance of MEAs 1-4, Figure 6, increased slightly when dry gases were replaced by synthetic reformate at the anode and was fairly constant during the first three cycles, increasing slightly afterwards for MEA 2 until the $7^{\text {th }}$ cycle and for MEA 3 until the $18^{\text {th }}$ cycle. The presence of water in the methanol mixture promotes the proton conduction in the membrane (and catalyst layer), but can also have a detrimental effect due to phosphoric acid leaching [25]; maintaining a sufficient amount of phosphoric acid in the membrane and catalyst layer is critical to maintain the fuel cell performance and to assure the durability [26]. Performing the cycles with reformate containing high content of methanol solution may lead to thickness reduction and mechanical degradation of membrane - causing formation of cracks and pinholes- as well as degradation of catalyst layer, especially at $180{ }^{\circ} \mathrm{C}$. Araya et al. [21] observed, upon introduction of methanol-water vapor mixture in the HT-PEMFC anode, a slight decrease in the ohmic resistance in chronologically early measurements, but the continuous introduction of methanol mixture resulted in the increase of resistance, at current densities between $0.22 \mathrm{~A} \cdot \mathrm{cm}^{-2}$ and $0.44 \mathrm{~A} \cdot \mathrm{cm}^{-2}$. In another report the same authors observed a negligible effect on ohmic resistance, at $0.2 \mathrm{~A} \cdot \mathrm{cm}^{-2}$, when hydrogen rich feed containing methanol water mixture was used in the anode feed [19]. In this work, EIS experiments were performed at $0.6 \mathrm{~A} \cdot \mathrm{cm}^{-2}$, leading at higher water production at 
the cathode. Also, when compared to the mentioned studies $[19,21]$, this work presents a water methanol solution with higher concentration on water.

The values of ohmic resistance obtained after 3, 7 and 18 cycles of synthetic reformate, using pure hydrogen as fuel (open symbols, Figure 6), do not differ greatly with the vales obtained at the end of the cycles.

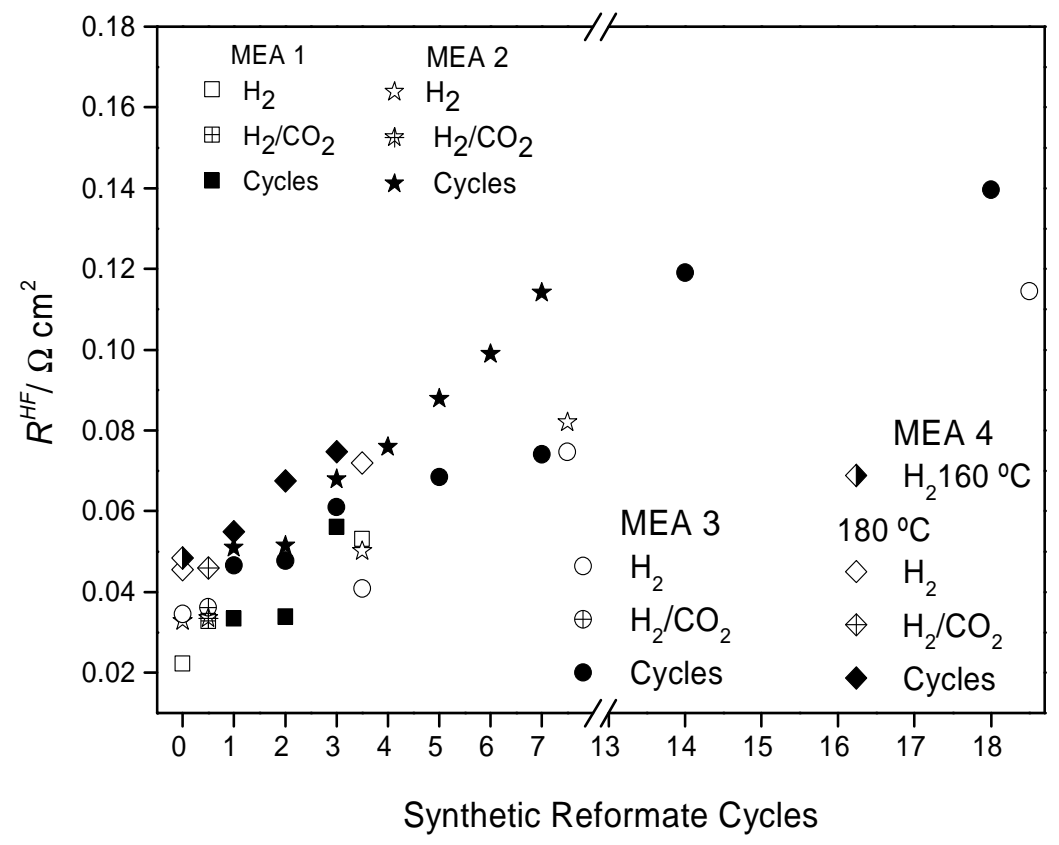

(a) 


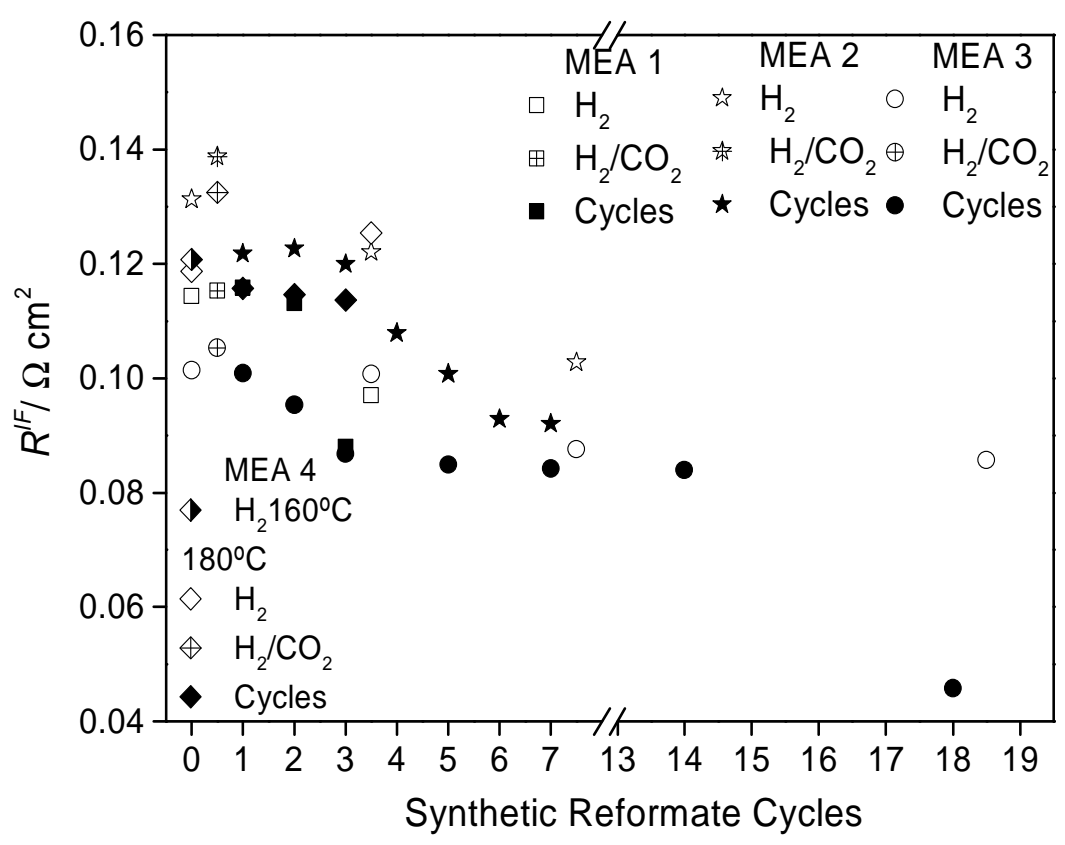

(b)

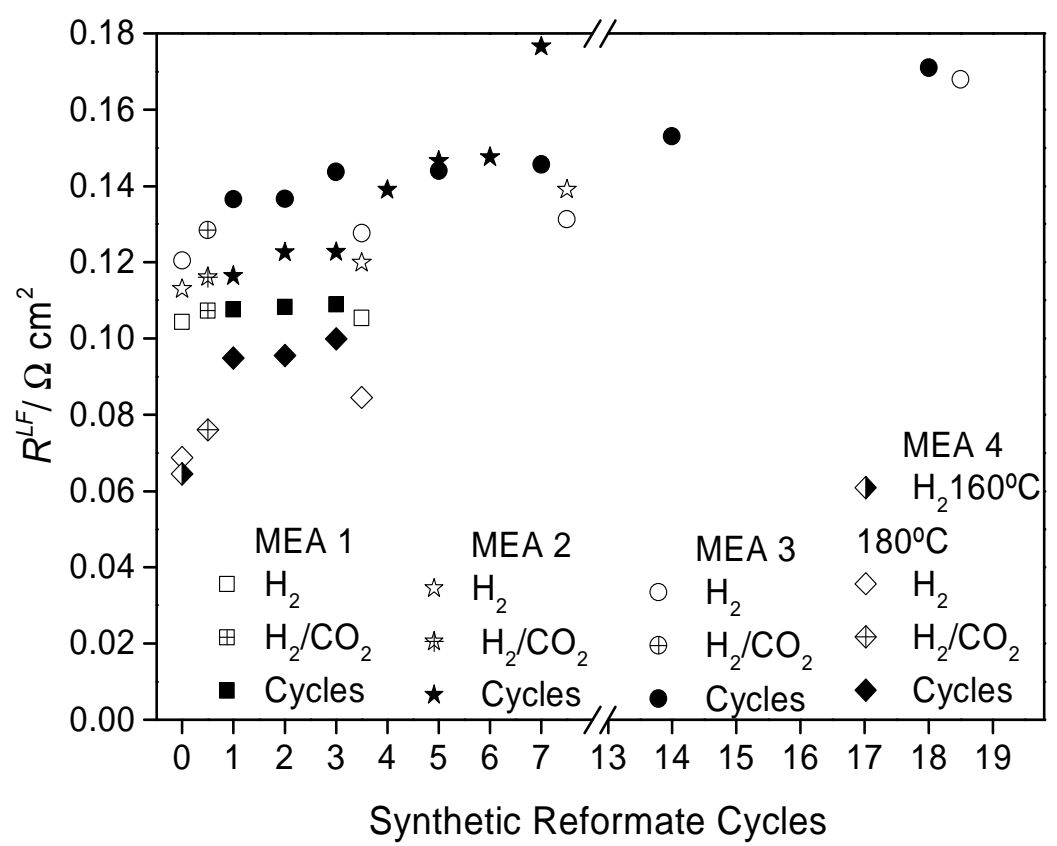

(c)

Figure 7 Fitted resistances for high (a), intermediate (b) and low (c) frequencies, for MEAs 1-4 and $0.6 \mathrm{~A} \cdot \mathrm{cm}^{-2}$ using different fuels: pure hydrogen (open symbols and half-filled symbols), carbon dioxide mixture (crossed symbols) and synthetic reformate (full symbols), at $160^{\circ} \mathrm{C}$ and $180^{\circ} \mathrm{C}$. 
The resistance obtained for high frequencies is associated with anodic processes, Figure 7 (a). For the four MEAs tested the high frequency resistance increased as the number of synthetic reformate cycles increased, showing a poisoning effect by the methanol. Methanol oxidation can occur through different parallel pathways with possible formation of $\mathrm{CO}$ and other intermediates such formaldehyde and formic acid [3, 18], increasing the anode overpotential. The pathway depends on the catalyst composition, temperature, electrode potential and the presence of oxygen donor species.

For the MEA tested at $180^{\circ} \mathrm{C}$, the value for the high frequencies resistance increased sharply during the three synthetic reformate cycles when compared to first three cycles MEAs 1-3. High temperature DMFC studies, based on a phosphoric acid PBI MEAs, showed that an increase in the operating temperature improves the kinetics of the methanol oxidation and induces a shift of electrochemical selectivity toward complete oxidation of methanol to $\mathrm{CO}_{2}$, reducing the formation of intermediates [3]. Worth noting, however, Galbiati et al. [24] studied of degradation of Celtec ${ }^{\circledR}$ MEAs in steady state, at $0.2 \mathrm{~A} \cdot \mathrm{cm}^{-2}$ and using pure hydrogen as fuel and they found that the voltage decay rate is higher at $180{ }^{\circ} \mathrm{C}$ when compared to $160^{\circ} \mathrm{C}$ due to an increase in the charge transfer resistance associated with the catalyst active area reduction and phosphoric acid losses from the electrodes.

The values of anodic resistance were also obtained after 3, 7 and 18 cycles of synthetic reformate, using pure hydrogen as fuel (open symbols, Figure 7 (a)). A partial recovery, associated to a decrease in the resistance values, was usually observed, similarly to what was already observed in the polarization curves, but was clear to some extent a permanent degradation. The permanent decrease in the voltage can be associated to the catalytic layer degradation, decrease of active area and phosphoric acid leaching.

The resistance obtained at intermediate frequencies, associated with cathodic processes, Figure 7 (b), presented a decreasing trend with the increasing number of cycles of synthetic reformate containing methanol solution. It was expected an increase of cathode losses due to methanol crossover and consequent oxidation in the presence of oxygen and platinum $[5,19,21]$. Furthermore, at $180{ }^{\circ} \mathrm{C}$, it is expected an increase in cathode tolerance to methanol, despite the possible increase in the methanol crossover [6]. The observed positive affect for all MEAs can be attributed to the humidification of the MEA by the water present in the synthetic reformate that decreased the charge transfer resistance associated to oxygen reduction reaction; when anode feed is humidified, water transport can occur from anode to the cathode [25]. Araya et al. also observed a decreasing trend of low frequency resistance (englobing the cathodic activities and the diffusion associated resistance) with increasing methanol slip [20]. 
A decrease in the intermediate resistance was obtained with pure hydrogen after 3, 7 and 18 cycles of synthetic reformate (open symbols, Figure 6 (b)) resulting from the removal of humidification from the anode fuel.

Finally, the resistance obtained at low frequencies, Figure 7 (c), associated with mass transfer in the gas diffusion layer, increased slightly when pure $\mathrm{H}_{2}$ was replaced with $\mathrm{CO}_{2}$ solution and afterwards with synthetic reformate, due to a decrease in the partial pressure of $\mathrm{H}_{2}$. For all the MEAs, the values were fairly constant throughout the first three reformate cycles. For the MEAs tested at $160{ }^{\circ} \mathrm{C}$ the resistance obtained after three synthetic reformate, using pure $\mathrm{H}_{2}$ as fuel (open symbols, Fig. 7 (c)) are very close to the values obtained with pure hydrogen just after activation; less so for the MEA tested at $180{ }^{\circ} \mathrm{C}$. Increasing the number of cycles of synthetic reformate (MEA 2 and MEA 3), lead to an increase of the low frequencies resistance.

\subsection{Post mortem analysis of MEA}

After electrochemical characterization, the phosphoric acid content in different sections of MEAs 1-4 was determined and compared to a reference MEA, Figure 8. The reference MEA was activated with hydrogen at $0.2 \mathrm{~A} \cdot \mathrm{cm}^{-2}$ during $70 \mathrm{~h}$ and no further electrochemical characterization was performed. An additional note is necessary: MEA 4 endured 7 cycles of synthetic reformate at $180{ }^{\circ} \mathrm{C}$ but a set-up shut down prevented the electrochemical characterization after 7 cycles (in section 3.1 and 3.2 only three cycles were considered).

The phosphoric acid content of the MEAs decreased with increasing number of synthetic reformate cycles performed. This result is consistent with the trend observed for the ohmic resistance (Figure 6) which increased slightly with the increase of number of cycles of reformate for each MEA. Both MEA 2 and MEA 4 endured 7 cycles with synthetic reformate, but at different temperatures. MEA 4 present lower a level of phosphoric acid in all MEA sections, but should be noted that this MEA presented a higher ohmic resistance just after activation (Figure 6) when compared to MEA 2.

The cell was feed as indicated in Figure 8, which may contribute to the good acid distribution in the MEA. 

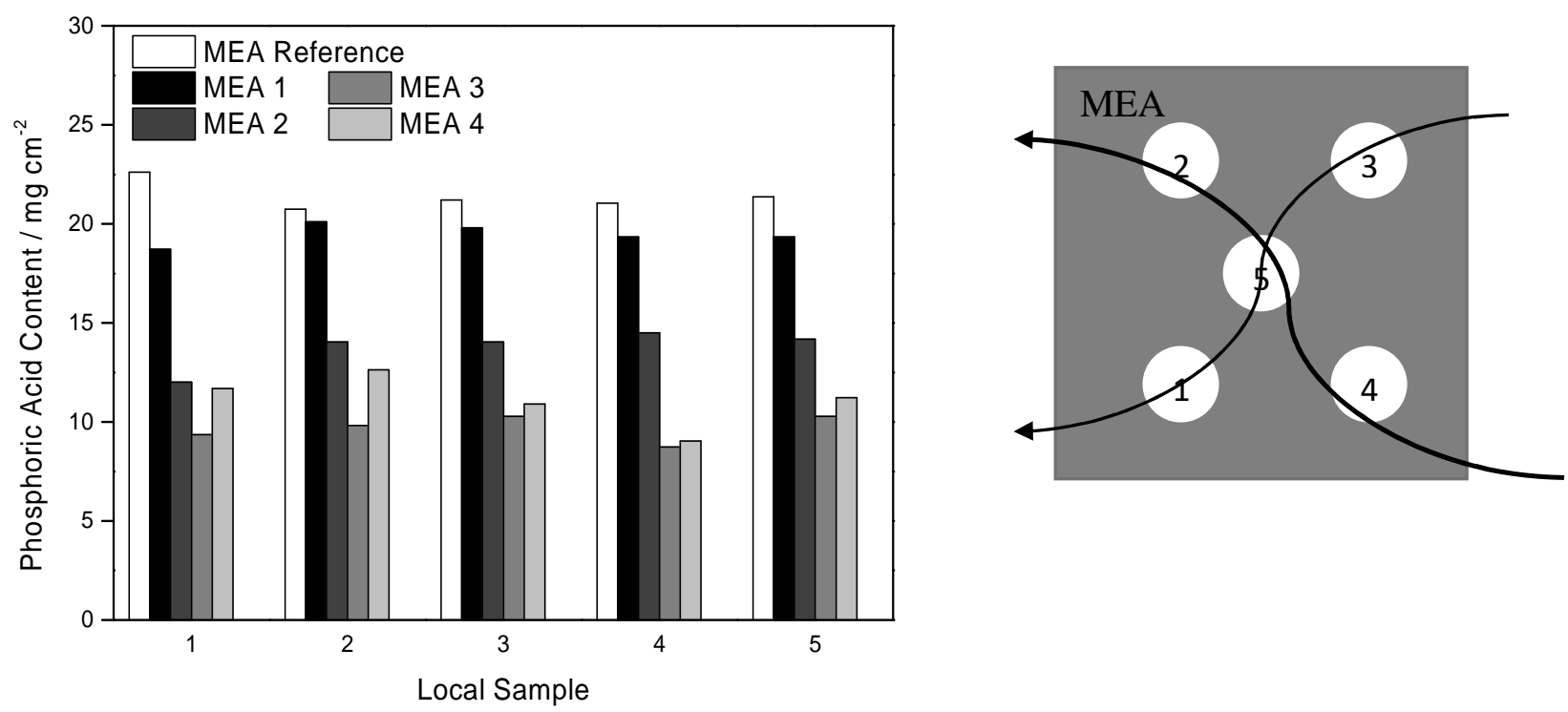

Figure 8 Phosphoric acid content at: 1- Cathode outlet, 2- Anode outlet, 3- Cathode inlet, 4- Anode inlet and 5- central section, for MEAs 1-4. A MEA scheme is added for clarity.

The post mortem analysis of the cross section of the tested MEA was performed to observe any possible microscopic changes. Figure 9 shows the scanning electron microscopy images of a Celtec ${ }^{\circledR}$ MEA that was tested with only with dry gases (pure hydrogen and $\mathrm{CO}_{2}$ mixture) after activation and the MEAs used for the present study.

The SEM images (all with the same scale) show that MEA 2, 3 and 4 (Figure 9 (c-e)) present more cracking of the catalyst layers when compared with the MEA that was tested only with dry gases (a) and MEA 1 (b), tested with three cycles of synthetic reformate.

An estimation of the doped PBI membrane thickness was performed by measuring the thickness of the membrane in several points and making the average. The average thickness of MEA $1(63 \pm 2 \mu \mathrm{m})$ increased when compared to the reference MEA $(47 \pm 2 \mu \mathrm{m})$. With increasing number of cycles however the thickness decreased, being lower than the value of the reference MEA (38 $\pm 2 \mu \mathrm{m}$ for MEA 2 and $34 \pm 2 \mu \mathrm{m}$ for MEA 3), as seen before for PBI membrane after a life test [27]. 


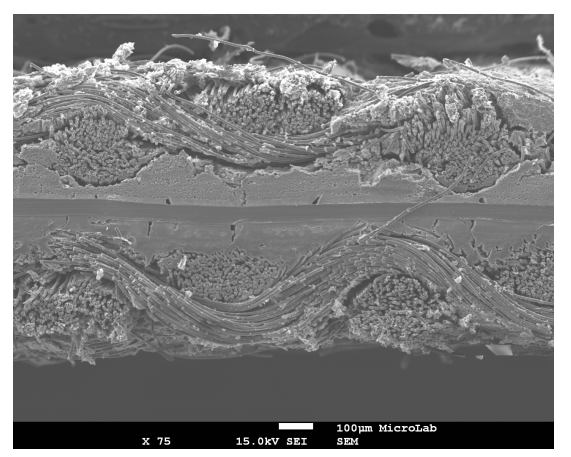

(a)

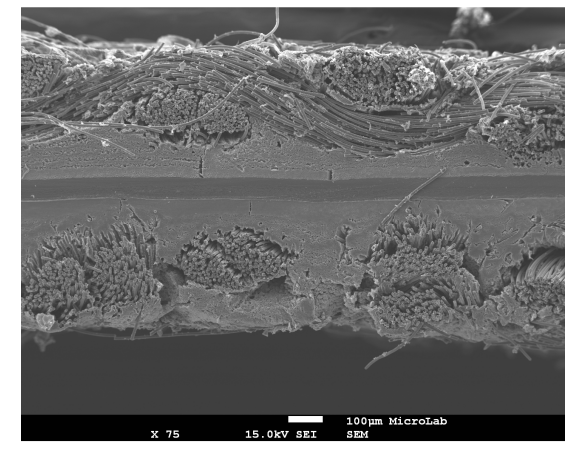

(b)

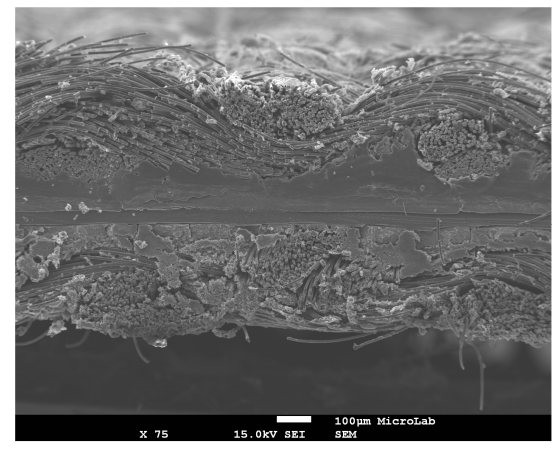

(c)

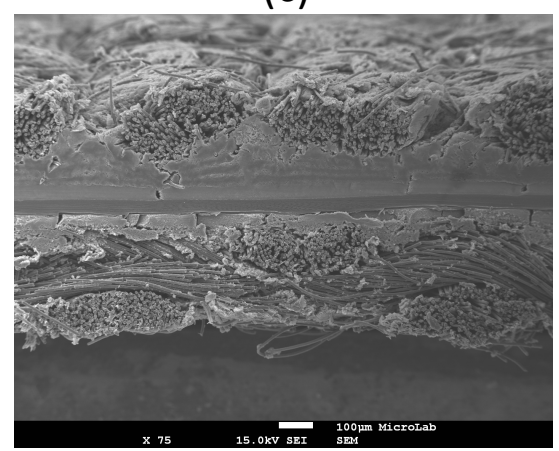

(e)

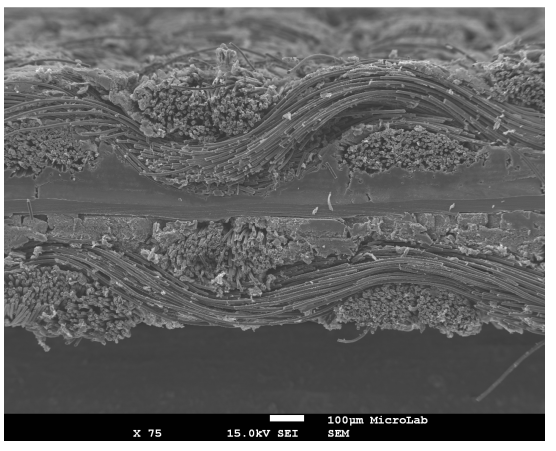

(d)

Figure 9 SEM micrograph of Celtec ${ }^{\circledR}$ MEA after electrochemical characterization tests: a) Reference MEA, b) MEA 1, c) MEA 2 d) MEA 3 and e) MEA 4.

\section{Conclusions}

In this work the influence of $\mathrm{CO}_{2}$ (up to $25 \%$ vol.) and non-reacted methanol solution (up to $10 \%$ vol.) in the performance of HT-PEMFC was evaluated using polarization curves and EIS analysis. Additionally a post-mortem analysis of the MEA was performed, namely SEM and determination of phosphoric acid content in different sections of the MEA.

The resistance associated to anodic processes increases with increasing number of synthetic reformate cycles due to the poisoning effect of the methanol. Additionally, the resistance associated with diffusion 
processes increases due to a decrease of the hydrogen partial pressure. These effects are more significant after supplying 7 cycles of synthetic reformate to the fuel cell anode. A positive effect was observed, however, for the resistance associated with cathodic processes due to water present in the synthetic reformate, that decreased the charge transfer resistance. The obtained results suggest that performing cycles of synthetic reformate containing methanol solution lead to a slight increase of ohmic resistance of the MEA due to phosphoric acid leaching. This assumption is corroborated by the determination of phosphoric acid content of the MEAs considered in this study; the increase of the number of cycles lead to a decrease of phosphoric acid content. Moreover, increasing the number of cycles with synthetic reformate lead to membrane thickness decrease.

The effects observed for HT-PEMFC when the synthetic reformate was supplied to the anode were partially recovered when pure hydrogen was used as fuel. Performing three cycles of synthetic reformate containing methanol, at $0.6 \mathrm{~A} \cdot \mathrm{cm}^{-2}$ does not significantly affect the fuel cell performance.

\section{Acknowledgments}

P. Ribeirinha acknowledge FCT (Grant PD/BD/52621/2014). The research leading to these results has received funding from the European Union's Seventh Framework Programme (FP7/2007-2013) for the Fuel Cells and Hydrogen Joint Technology Initiative under grant agreement $\mathrm{n}^{\mathrm{o}} 303476$ (www.beingenergy.eu). 


\section{References}

[1] Zhang JL, Xie Z, Zhang JJ, Tanga YH, Song CJ, Navessin T, et al. High temperature PEM fuel cells. J Power Sources. 2006;160:872-91.

[2] Deluca NW, Elabd YA. Polymer electrolyte membranes for the direct methanol fuel cell: A review. J Polym Sci Pol Phys. 2006;44:2201-25.

[3] Lin WF, Wang JT, Savinell RF. On-line FTIR spectroscopic investigations of methanol oxidation in a direct methanol fuel cell. J Electrochem Soc. 1997;144:1917-22.

[4] Wang JT, Wainright JS, Savinell RF, Litt M. A direct methanol fuel cell using acid-doped polybenzimidazole as polymer electrolyte. J Appl Electrochem. 1996;26:751-6.

[5] Wang JT, Wasmus S, Savinell RF. Real-time mass spectrometric study of the methanal crossover in a direct methanol fuel cell. J Electrochem Soc. 1996;143:1233-9.

[6] Lobato J, Canizares P, Rodrigo MA, Linares JJ, Lopez-Vizcaino R. Performance of a vapor-fed polybenzimidazole (PBI)-based direct methanol fuel cell. Energ Fuel. 2008;22:3335-45.

[7] Andreasen SJ, Vang JR, Kaer SK. High temperature PEM fuel cell performance characterisation with $\mathrm{CO}$ and $\mathrm{CO} 2$ using electrochemical impedance spectroscopy. Int J Hydrogen Energy. 2011;36:9815-30.

[8] Boaventura M, Sander H, Friedrich KA, Mendes A. The influence of CO on the current density distribution of high temperature polymer electrolyte membrane fuel cells. Electrochim Acta. 2011;56:9467-75.

[9] Chen CY, Lai WH, Chen YK, Su SS. Characteristic studies of a PBI/H3PO4 high temperature membrane PEMFC under simulated reformate gases. Int J Hydrogen Energy. 2014;39:13757-62.

[10] Das SK, Reis A, Berry KJ. Experimental evaluation of CO poisoning on the performance of a high temperature proton exchange membrane fuel cell. J Power Sources. 2009;193:691-8.

[11] Modestov AD, Tarasevich MR, Filimonov VY, Davydova ES. CO tolerance and CO oxidation at Pt and $\mathrm{Pt}-\mathrm{Ru}$ anode catalysts in fuel cell with polybenzimidazole-H3PO4 membrane. Electrochim Acta. 2010;55:6073-80.

[12] de Bruijn FA, Papageorgopoulos DC, Sitters EF, Janssen GJM. The influence of carbon dioxide on PEM fuel cell anodes. J Power Sources. 2002;110:117-24.

[13] Pan C, He RH, Li QF, Jensen JO, Bjerrum NJ, Hjulmand HA, et al. Integration of high temperature PEM fuel cells with a methanol reformer. J Power Sources. 2005;145:392-8.

[14] Su A, Liu Y-C, Lin W-C, Cheng C-K, Hsieh C-Y. A Study on the Integration of Micro-reformer and High- Temperature PEM Fuel Cell. Heat Trans Asian Res. 2010;8:611-8. 
[15] Avgouropoulos G, Ioannides T, Kallitsis JK, Neophytides S. Development of an internal reforming alcohol fuel cell: Concept, challenges and opportunities. Chem Eng J. 2011;176:95-101.

[16] Avgouropoulos G, Neophytides SG. Performance of internal reforming methanol fuel cell under various methanol/water concentrations. J Appl Electrochem. 2012;42:719-26.

[17] Avgouropoulos G, Paxinou A, Neophytides S. In situ hydrogen utilization in an internal reforming methanol fuel cell. Int J Hydrogen Energy. 2014;39:18103-8.

[18] Iwasita T. Electrocatalysis of methanol oxidation. Electrochim Acta. 2002;47:3663-74.

[19] Araya SS, Andreasen SJ, Nielsen HV, Kaer SK. Investigating the effects of methanol-water vapor mixture on a PBI-based high temperature PEM fuel cell. Int J Hydrogen Energy. 2012;37:18231-42.

[20] Araya SS, Grigoras IF, Zhou F, Andreasen SJ, Kaer SK. Performance and endurance of a high temperature PEM fuel cell operated on methanol reformate. Int J Hydrogen Energy. 2014;39:18343-50.

[21] Araya SS, Andreasen SJ, Kaer SK. Experimental Characterization of the Poisoning Effects of Methanol-Based Reformate Impurities on a PBI-Based High Temperature PEM Fuel Cell. Energies. 2012;5:4251-67.

[22] Boaventura M, Mendes A. Activation procedures characterization of MEA based on phosphoric acid doped PBI membranes. Int J Hydrogen Energy. 2010;35:11649-60.

[23] Tingelof T, Ihonen JK. A rapid break-in procedure for PBI fuel cells. Int J Hydrogen Energy. 2009;34:6452-6.

[24] Galbiati S, Baricci A, Casalegno A, Marchesi R. Degradation in phosphoric acid doped polymer fuel cells: A 6000 h parametric investigation. Int J Hydrogen Energy. 2013;38:6469-80.

[25] Galbiati S, Baricci A, Casalegno A, Marchesi R. Experimental study of water transport in a polybenzimidazole-based high temperature PEMFC. Int J Hydrogen Energy. 2012;37:2462-9.

[26] Kim JR, Yi JS, Song TW. Investigation of degradation mechanisms of a high-temperature polymerelectrolyte-membrane fuel cell stack by electrochemical impedance spectroscopy. J Power Sources. 2012;220:54-64.

[27] Liu G, Zhang HM, Hu JW, Zhai YF, Xu DY, Shao ZG. Studies of performance degradation of a high temperature PEMFC based on H3PO4-doped PBI. J Power Sources. 2006;162:547-52. 